\title{
Political Elitism in Nigeria: Challenges, Threats and the Future of Citizenship
}

\author{
Oluwasegunota F. O. Bolarinwa, Ucheoma C. Osuji \\ Department of Philosophy, Adekunle Ajasin University, Akungba-Akoko, Nigeria \\ Email: oluomobola15@gmail.com, ucheoma.osuji@aaua.edu.ng
}

How to cite this paper: Bolarinwa, O. F O., \& Osuji, U. C. (2022). Political Elitism in Nigeria: Challenges, Threats and the Future of Citizenship. Open Journal of Philosophy, 12, 105-122.

https://doi.org/10.4236/ojpp.2022.121007

Received: December 30, 2021

Accepted: February 19, 2022

Published: February 22, 2022

Copyright (c) 2022 by author(s) and Scientific Research Publishing Inc. This work is licensed under the Creative Commons Attribution International License (CC BY 4.0).

http://creativecommons.org/licenses/by/4.0/ (c) (i) Open Access

\begin{abstract}
This paper explores the impacts of political elitism in Nigeria. This is informed by our past experiences and present realities of Nigerian political elites that play exclusionary politics which this paper interrogates. It argues the thesis that there is need for inclusive governance and political participation in order not to turn Nigeria into a fragile state. The purpose of this is to ensure that good governance is achieved and sustained. This is based on the reason that political relationships between elites and citizens dictate development outcomes. Delivering development involves working with the political dynamics that has citizens' welfare as its focus. It does this by addressing social justice and extremes of inequality as "bottom-up" as well as "top-down" political, social and economic processes that sustain effective states, efficient markets and vibrant societies. Governance describes the way states and societies manage their affairs politically and the way power and authority are exercised. Entrusting governance to a few people that constitutes the political class endangers development, political participation and settlements. It also increases cycles of poverty among citizens that do not belong to the elite class. This reinforces the argument of the thesis that political elitism creates poor relations and hinders economic development and sustains fragile citizenship. Hence, this paper adopts critical phenomenology as its methodology to redefine political participation with inclusiveness while dismantling the tempting tendencies of political elitism and corruptive practices that stagnate governance and development. This paper submits that inclusive political participation will ensure that governance is centralized and built on finest philosophical ideals for overall nation building for the benefit of Nigerian citizens. By this, Nigeria will not be left in the hands of few less sensitive political elites.
\end{abstract}

\section{Keywords}

Elites, Political Elitism, Citizen, Africa, Democracy, Governance, Exclusionary Politics 


\section{Introduction}

The issue being interrogated in this study is political elitism which underscores politics of exclusiveness. The problem we have had to grapple with here is that the threats and challenges political elitism throws on citizenship, and governance, which have multiplier effects on nation building. One of the perplexing questions in political philosophy is "who should rule?" The question of political elites tends to present the ultimate question of what ought to be the ultimate justification of the existence of any form of government within political organization. The answer to such questions seems not naturally to emerge from an ethical theory such as utilitarianism which proposes the greatest happiness for the highest number. From the classical theories, we discover that the idea of political elites dates from the Greco-Roman world. The political activities and determinism placed on the nation-state by the political elite is what we refer in this paper as "political elitism." Political elitism as Biggs (2019: p. 3) observes, characterizes many political organisations in the world. Political elite is a status group among citizens of a nation-state (Odubajo \& Alabi 2014: p. 121). Political elite is a "power elite": overlapping social and economic networks. The group is less than one percent $(\leq 1 \%)$ of the populace. Elite exercises disproportionate power; the extent of this power varies with issue, over time; across states. They have various mechanisms to control the populace, from direct to indirect rules, mechanism and information. They exercise four levels of power: occupying; prevailing; preventing; manipulating (Odubajo \& Alabi 2014: p. 124; Matthew, 2007, 2012; Murshed \& Gates, 2005). They exert economic control as managers; non-executive directors (Biggs, 2019: p. 3) as well as interlocking directorships integrate all major companies.

There are some words we employ in this paper which we must first analyze before grappling with the problems of elitism in Nigeria. First is the term-politics; which is itself unpredictable and characterized with greater degree of uncertainty. The rules of the game are unknown and as such the need for distinctive science of politics becomes necessary in order to actualize the desired outcome of politics. Understanding the centrality of politics in building effective states and shaping developmental outcomes is crucial. It shows that "politics" is not an abstract concept, but an essential determinant of the Millennium Development Goals (MDG) that is, better educated, healthier, more prosperous people (Orelope-Adefulire, 2022: p. 2). These goals provide evidence of politics as the "driver of change" and as the ultimate cause of people's prosperity, security and access to justice. It shows how local political economy influences national status in global politics, state fragility and the ability of citizens to participate in their own development. Politics helps a nation-state to deepen an understanding of how horizontal inequalities created conflict. In this paper, politics is used as an index to measure of citizens' participation in Nigeria government.

Political settlement describes the types of informal as well as formal political bargains that can end conflict and bring sustainable peace, promote reform, de- 
velopment and poverty reduction or fail to achieve any such progress (Neera, 2010; Langer, 2009): On the other hand, exclusionary politics are associated with high levels of violence and poor development outcomes (Ezeajughu, 2021; Babarinsa, 2003). Negotiating or renegotiating political settlements to reduce exclusion is particularly important in conflict and post-conflict situations. Where power resides within the state, elite interests involve compensation in return for their agreement to relinquish claims to power. Indeed, comparative case studies ${ }^{1}$ suggest that who is included in the political settlement matters greatly. Political settlement explains why similar forms of political organisation and administration produce startlingly different development outcomes. Policy-makers and researchers share an interest in understanding how the balance of power between elites and social groups affects the ability of modern states to end conflict and build durable nation-states. We need to know why an electoral process in one state achieves coalitions for change, but the same process in another state leads to political instability and even conflict. Political settlement in Nigeria has gone a long way to determine who gets what. It has evolved from regional politics (Moro, 2006; Eke et al., 2005; Mustapha, 2009), to political "godfatherism" (Isaac, 2005: pp. 79-105) and this has degenerated the quality of governance turning Nigeria into fragile state. This has multiplier effects which the Nigerian citizens have had to grapple with.

The methodology of this research is critical phenomenology. Critical phenomenology allows the use of primary and secondary sources. The primary sources are eye-witness account, oral interviews, diaries and archival materials while the secondary sources are written documentaries, books, internet, newspapers, magazines, journals. It is a useful and fertile style of thinking; the strength of phenomenology lies in its interdisciplinary appeal (Unah, 2002). It is on the one hand a conceptual system within the history of philosophy. This provides a deeper access to the fullness of phenomena as they present themselves to human consciousness. In this paper the primary sources will be delineated and the core issues will be presented. The essence of the secondary source is that they will enable the understanding of the historical developments and the origins of the problem of political elitism. Thus, the secondary sources include the classical theories (which offer advice for achieving an ideal society) and modern theories (which are primarily devoted to what we call philosophical analysis). This research will answer the following questions: How did political elites come about in human history and in Nigeria? What influences has Nigerian elites over governance, state of the nation, development and structures? What are the roles of Nigeria elites in nation-state building process? How can active citizenship shape development in Nigeria? These questions are necessary because there is need to understand how the balance of power between elites and social groups affects the ${ }^{1}$ Patterns of inclusion or exclusion within the political organisations that control the state can go a long way toward explaining the outbreak of civil wars in some Sub-Saharan, (Lindemann, 2008) African countries, such as Uganda (DFID, 2021: p. 15) and Cote d'Ivoire (Langer, 2005: p. 25), where major groups were permanently excluded from power. Conversely, inclusive bargains can explain the absence of conflict in places like Zambia (DFID, 2021: p. 15), Tanzania and Ghana (Lindemann, 2008). 
ability of modern states to end conflict and build durable states.

The paper is divided into five sections, beginning with this introduction. Here, we introduce the problem of the research, and attempt conceptual clarification to enable a vivid understanding of some of the words used in this study. Section two discusses the historical foundation of political elitism from a philosophical perspective. Here we discovered that political elites date long ago from history. The idea came from the Greco-Roman world as it is largely reflected in Plato's Republic. This same idea is a key idea in the postulations of the contractarian philosophers (Hobbes, Locke, Rousseau), even though there are differences in their ideologies in terms of where sovereignty resides. The third section states the background and paradoxes of political elitism in Nigerian democracy. We discover that there is inconsistency and absurdity in the practice of elitism in Nigeria. This leads us to question the role of elites in the Nigerian State. Thus, the fourth section addresses the role of elite in democratic states. It also analyzes the difference between democracy and autocracy. Furthermore, it discourses the challenges and threats posed by political elitism in a democratic Nigeria. Thereafter, conclusion and recommendation follows as the last section.

\section{Understanding the Philosophical Foundations of Political Elitism}

The history of political elitism can be traced to Plato's categorization of the ruling class in the Republic. Plato designates ruling of the society to a group of people who are trained in arts of leadership to be the guardian of the society. The ruling class constitutes the rational elements of the society, the soldiers are the spirited elements and the other citizens are the appetitive elements. An ideal society will be one in which all these elements function harmoniously (Popkin \& Stroll, 2009: p. 72). The guardians must be given absolute authority in running the society; hence, the foundation of political elitism. A contest of political elitism can also be seen in the middle ages where there was a clash between the Church (Papal authority or the ecclesiastical authority) and the emperor. The crux of the matter was to determine in their society whose power is sovereign. The Pope had a universal authority and one of the most striking aspects of society after A.D 1000. The ban of ex-communication was a far deadlier weapon than ever the strongest arm method employed in the secular society (Itanrin et al., 2018: pp. 235-236). There was difficulty in trying to harmonize the temporal claims of the king (for instance in Germany) with the far more intangible, but universal, spiritual authority of the Pope. This gave rise to repeated wars among the two sides: the positions of the Emperor and the Pope were real complex relation between the spiritual and secular authorities (Leff, 1965: p. 80).

In modern era, there were lots of political theories proposed by so many philosophers, such as Thomas Hobbes, John Locke, and Jean Jacques Rousseau which attempt to answer the question of who should rule? These three philosophers envision a state where the origin of leadership began. They proposed their theories from a vantage position. Hobbes proposed a "state of nature" where people 
lived in their natural life. In the bid to protect their lives and properties will by the use of reason make natural laws. These natural laws will guide them in living their lives. But as a result of those who will disobey these natural laws from natural reasons, the issue of obligation comes up. It is in the bid of obligation to natural law that the society is transformed from a state of nature into a civil society through social contract. Hobbes writes:

the contract by which people avoid the state of nature and enter into civil society is an agreement between individuals; as if every man should say to every man, I authorize and give up my right of governing myself, to this man or this assembly of men, on this condition, that thou give up thy right to him and thy authority; all thy actions in like manner (Stumpf, 1983: p. 233).

Hobbes believes that there is need for a man or group of men to lead others. These men were given sovereignty by all in order to attain a civil society. John Locke began by opposing Hobbes idea of "state of nature" that it is a "state of war." For him, state of nature still guarantees its members life, liberty and passion of private property (Popkin \& Stroll, 2009: p. 82). There would be no reason for men to leave the state of nature and form societies, expect that difficulties arise in applying punishment to those who transgress the law (Popkin \& Stroll, 2009: p. 83). Locke was the theoretical architect of democracy in the western world today. Thus society originates in the attempt to develop such institution for the purpose of remedying the defects of life through organized society. Men create a society by voluntary agreement among themselves to erect these institutions. The basis of government is laws, not force. A government without law will be tyrannical. For Locke, the source of authority lies with the people who elect the government. It is merely a means for carrying out their will (Popkin \& Stroll, 2009: p. 85). The history of political philosophy can be looked at in terms of the question "who should rule?" Plato, Hobbes, and most of the political theorist up to Locke agreed that individuals or special group should rule. Locke gave powerful argument in favour of the rule of the people by the people, which is interpreted as the rule of majority. J. J. Rousseau contends that sovereignty resides in the general will. The determination of who should rule depends on the population of the society. For small size population, he recommends participatory democracy, while for medium size population should be ruled by aristocracy and large scale population should be ruled by monarchical system. This shows that human history has been a history of who rules.

\section{The Paradoxes of Political Elitism in Democratic Nigeria}

\subsection{Nigeria Political Elitism: Background and Problematics}

The Nigeria political elites are also referred to as power elites. Historically, Nigerian elites have been a faulted bourgeoisies in the sense that their social position, economic pre-eminence and even values and personalities were shaped by colo- 
nialism (Graf, 1983: p. 120). These political elite in Nigeria are a conglomeration of individuals who occupy and/or once occupied strategic position in all the political, economic and social institutions in the country. These individuals collectively make policies that affect the life chances of every Nigerian (Ogbeide \& Aghahowa, 2005: p. 222). Specifically these political elites include the President, Vice president, State Governors, Deputy Governors, Local Council Chairmen and Vice Chairmen, Federal and State Legislators, Judges of the High Judiciary, Officers Corps (both serving and retired in the arm forces) the police, political party leaders (Ogbeide \& Aghahowa, 2005: p. 222). It also includes members of Council of State, Federal ministers, State Commissioners, Chairmen of Boards Parastatals, Permanent Secretaries of Public Service, Ambassadors, Directors and Deputy Directors. It also includes multi interest entrepreneurs, single interest entrepreneur, building and construction contractors who receive major government contracts, proprietors of sizable shops or hotels, bank managers, transporters, exporters/importers and managers of insurance companies.

Furthermore, the list includes Traditional rulers (patronized by governments), religious leaders (Moslems and Christians) and University Dons, particularly those who have joined business and politics equally belong to the power elites. Generally, these power elites occupy the commanding heights of the Nigerian political economy. Another way to understand how political elitism emerges is when we analyse how power is distributed in democratic government. Three major divisions are seen having stakes in government and governance. They are: Median voter (parties converge at the centre of preference distribution), Pluralism: (different coalitions of interest groups and voters; prevail on different issues; dispersed inequalities, and power elites (power wielded by corporate owners/managers overlapping with “upper class”) (Mills 1958; Domhoff, 1978).

These political elites control the nation by direct and indirect mechanisms. By direct mechanisms, they use identity, ethnicity, and religious sentiments to protect their self-interest. They mobilize human and material resources to win elective offices. These come from the economic elites (and also trade unions). Politicians and officials know they can ascend into elites' class. They demand financial returns from those they install into positions of public confidence in form of stolen money, falsified contracts from political office holders and grossly inflated government contracts handed over to the elites. These elites do not occupy formal leadership positions rather they choose and sponsor the leaders who may act on their behalf and by extension, of others. With this, they prevail over others. In political conflict, they exercise power, influence and rule indirectly. Power then becomes "the probability that one actor within a social relationship will be in a position to carry out his own will despite resistance" (Osuji, 2018: p. 149). They also prevent others from creating political conflict in many ways, through negotiations, threats or agenda-setting. They also exercise power by manipulating others to accept their interests as people's interests. But, it is doubtful giving some recent incidents whether some of the ruling elites in both public and pri- 
vate sectors, in and out of government in Nigeria, despite hard lessons of the past, are genuinely committed to the emergence of a new and positive culture of leading (Agbaje, 2014: p. 103). This calls attention to the conception of "political settlement"; this represents the forging of a common understanding, usually between elites, that their best interests or beliefs are served by a particular way of organising political power (Di John \& Putzel, 2009). It forms the relationship between formal and informal institutions and the distribution of power in society. North et al. (2007) argue that in responding to the challenge of limited resources, elites aim to maximise their control over those resources, especially to unearned income. This manifests in politics of deceit, dominated by "negative frills" and effervescent self-seeking leadership; this is the main source of societal disenchantment which sponsors underdevelopment.

\subsection{The Paradoxes of Elite Transformation in Democratic Nigeria}

The problem which political elites group and their elitists' movement are creating in Nigerian democratization process is unimaginable. This problem is paradoxical and is understood in three senses. First from a strictly etymological perspective, the transition from autocracy to democracy should involve moving from "the rule of one person (or small group of persons)" to "the rule of the people (or to that segment of the people possessing equal political rights as citizens)." In the former, the government consists of a political elite clearly demarcated from and not accountable to the population; in the later, either there is no elite and citizens govern directly or they govern indirectly through agents chosen by them, but who only rule pro tempore and depend periodically on their explicit consent. As the result of such a change in regime, there should be a complete change of elite personnel and structure. Moreover, the ensuing governing elite (or non-elite) is expected to pursue different policies benefitting different segments of the population. In Nigerian democracy, we do not find the shift in democracy. What is practiced is in transition is typical resemblance of autocracy. There is seen where formal military President becomes civilian and make "come back" as civilian Presidents in the same country.

Secondly, from a realistic perspective, the roles of elites and their policies in the process of regime transformation are not so simple. The elites mastermind lots of intrigues and manipulations. Thus the roles of individual representatives who act as intermediaries between the citizens and their rulers become crucial (Osibanjo, 2021). But again, if these roles are not properly defined, some of these representatives eventually become rulers and invariably elite members. The implication here is that the difference between autocracy and democracy is bound to be less dramatic. Instead of rule by a few verse rules by all, we have "rule by some politicians" or "polito-cracy" (Schmitter, 2021: p. 3) which is typical of Nigerian democracy. These newly empowered representatives inevitably form ruling elites institutionally separate from the electorate that has chosen them competitively or the electorate that have chosen them for their reputation. 
How can this ambiguous process of elites' transformation be the model of regime transition in Nigeria democratic governance? There has to be explanation of how a given polity changes from autocracy to democracy and verse versa. This transition does not just happen in the type of political system but is also founded in terms of political interest, and ideological representation. This means that nothing has actually changed since many actors in the "new" democratic elite inherits from the ancien régime. This is seen in the ways political parties are easily formed in Nigeria, these politicians run into one party today and come out of it, and jump into another easily. If this were not enough, as we have been reminded by numerous theorists and empirical researchers, these elected or selected politicians (Ezeajughu, 2021) may form a class ${ }^{2}$ to which there are formidable barriers to entry by competition and unwanted members to avoid competition from outsiders and/or succeed in invoking conformity by convincing the people of their unique and hegemonic "right to rule."

Thirdly, more recently, another factor has intervened to complicate this mediated relation between citizens and rulers, namely, the trend toward the professionalization of the nature of representation and, hence, the status of politicians in both political parties and civil society. Initially, in liberal democratic theory, it was presumed that the tenure of politicians was limited in time and commitment, either by the outcome of competition between political parties or by personal choice when the winners (elected or non-elected) decided to return to their original life situations. In short, politicians were presumed to live "for politics," not "from politics." In well-established democracies, this trend toward the latter has already been extensively documented. But in newly-created democracies, it seems to set in very quickly as the amateurs at the beginning of regime transformation become professionals by its end.

From republican to princely government, the generic situation is similar when moving from autocracy to democracy. And the implication is identical (Schmitter, 2021: p. 3). During the period when one regime is in demise or transforming itself, what becomes much more important than during "normal times"; when necessità was embedded predictably in a pre-established and hegemonic set of rules; are the autonomous choices of actors (he calls it virtü) in choosing and institutionalizing a new set of rules (Schmitter, 2021: p. 3). Ergo, not only may the period of transition result in a change of the ruling elite (or for Machiavelli, the single ruler), it also provides the agents involved with an unusual degree of discretion in making these choices (Schmitter, 2021: p. 3).

If this were not enough, all real existing democracies depend on non-democratic elites that are embedded in the so-called "guardian institutions" of the state agencies, commissions, directorates, boards, central banks, courts, administrative staff and so forth (Schmitter, 2021: p. 3); that may be delegated certain powers by democratic elites, but are expected to take their binding decisions based ${ }^{2}$ This is seen in the way some members of Action congress (AC), and other members of different political parties succeeded in winning the 2015 presidential election in Nigeria through joint forces and collaboration of selected political elites. 
on their expertise (civilian or military) and, therefore, deliberately protected from the vicissitudes of political competition. Needless to say, the continuity of these elites is likely to be even greater during and after the transition from autocracy to democracy than that of elected or selected political representatives. The Nigerian democracy looks like electoral autocracy where the Nigeria citizens were forced by the political elites to accept quasi democracy (Onyishi, 2018: p. 48). This is a situation where a formal emphasis on election purports to mask the absence of real accountability and the continuity importance of elite-centred patronage politics. Lackey (2012: p. 123) notes that on this ground, Nigerian federalism has degenerated into a structure that simplify and accommodate a multiplicity of decentralized and lawless political spaces (its 36 states and 774 local governments) along with small patches of political turf that are not formally delineated. It is these elites that decide for the Nigeria (Olaopa, 2021; Kia \& Vurasi, 2013: pp. 161-172).

\section{The Challenges, and Threats Posed by Political Elitism on the Future of Citizenship in Nigeria}

\subsection{The Trend of Political Elitism in Nigeria}

Of course no nation-state is without its own elites. These elites include the founding fathers of the Nation-state. In the past Nigeria's elites like Nnamdi Azikiwe, Obafemi Awolowo, Ahmadu Bello and many of others were visionary leaders who desired a greater nation-state. Today, one of the challenges facing Nigerian state is the problem of political elitism. Nigeria is also facing problems of political instability, insecurity, bad governance, gender inequality and several others orchestrated by her elites (Agbaje, 2014; Odubajo \& Alabi, 2014: p. 122). At the heart of these problems are the political elites. These elites in Nigeria use their influence to create instability in government, economic recessions, (Kia \& Vurasi, 2013), thereby turning the country into fragile state. The activities of these elites create poor governance, insecurity engendering negotiation with unknown faces, "fictional tribes and tribal fictions". These elites develop "divide and rule" ideologies in other to remain in power. They influence the trend of development; for instance who gets what in Nigeria and why. They also use force and violence to get what they want especially during elections and electoral process. They create class and calibre in such a way that the poor is insecure, hungry, underdeveloped and less empowered in such a way that the citizens now understand that "governance is intrigues" in Nigeria. The activities of political elites are killing the policies that unite and sustain Nigerians, Nigerian economies and its developmental structures.

Nigeria political system has in it much diversity which ranges from political structuralism and foundation upon which the political elites and politicians built it. The 2019 elections in Nigeria were characterized by bargains between the political elites and social groups (Ezeajughu, 2021: p. 193ff). Governance in Nigeria is now characterised by politicians striking informal "bargains" that build on 
their relationships with particular social groups, but that frequently undermine formal state rules, laws and regulations with damaging effects and negative impacts for the nation-state. There is need to recognize the centrality of politics to all governance issues. The need to recognize what type of bargain goes on between the elites in the state and social or pressure groups is necessary. This will enable us monitor key interested political citizens as well as understand and recognise that effective, efficient and accountable public authority evolves through a political process of bargaining between elites and between the state and organised groups in society.

Political context and processes are central to shaping the way politicians and policy makers decide for or against progressive changes that can deliver legitimate, capable, accountable and responsive states. This will in the long run help explain their processes which will enable the attainment of progress in terms of economic growth and political stability while others remain locked in conflict and poverty (Odubajo \& Alabi, 2014: p. 138; Agbaje, 2014: pp. 103-106). Besides, it has provided evidence and analytical tools to show how to work with the structures, relationships, and interests that support or undermine change. However, while all these have helped with the design of country's programmes and projects, we still need a better understanding of the politics of development and how elites influence it for faster poverty reduction. This is opened for research in order to unravel this new order of governance agenda. Elites, elite's incentives and intentions to pursue developmental aims are critical. The list of factors determining elite incentives has too often been described in purely domestic terms, where international communities often have limited influence and domestic elites are easily portrayed as "lacking political will", intransigent or venal. But research has shown that some features of the global environment can create perverse incentives for political elites to perpetuate the fragility of states, and to destroy state capacity. Politicians may deliberately govern badly because globalisation has generated perverse incentives making it more tempting to take this course. But then, contemporary elites may live in a globalised environment but the pursuit of their interests may be one of the factors weakening the positive incentives for the state-builders of the past, as seen in Nigeria.

To some ambitious people in countries like Nigeria, Colombia, Haiti, Zambia, or Pakistan, the important signals come not only from what the developed world advises, even when that is backed by aid fund (Osuji, 2018: pp. 149-150); but the behavioural incentives created by rich countries in a globalised world. First, wealthy countries are willing to pay such high prices for scarce commodities like oil, gas, diamonds and Colten. Hence, they signal clearly that getting a share in the huge surpluses to be earned from extracting and exporting such products is a good way to get ahead in the South. Second, the willingness of some people in the developed world to pay good money for recreational narcotic (even though their governments make them illegal) creates a major transnational industry. We see these in the whole of Africa where external interests becomes elites motives 
and reasons to destabilize the economy in the face of personal gains in Nigeria and the rest of Africa.

\subsection{Political Elitism in Contemporary Nigeria}

The Nigerian elites have turned Nigeria into fragile state ${ }^{3}$ (Olowu \& Chanie, 2016: pp. 1, 4-5), while others will prefer failed states (Rotberg \& Campbell, 2021; Kinnan, 2021). The media (social, print, radio, television) echo same failure exhibited by these elites. The members of the Nigerian political elite have always failed to convince the rest of the citizens that whatever they do in politics and business was for the interest of every Nigerian. The most recent is the agitation between Nigeria Banks and telecommunication companies over tariffs rate (https://www.Lindaikeji/blog:2021). Historically, it was the conflict among the political elites that led to the civil war (1967-1970) in which millions of Nigerians irrespective of social classes lost their lives. The resource control debates was a manifestation of the perennial conflicts among the Nigerian power brokers over who gets what and how much from the enormous revenue accruing to the national government from the sales of petroleum (Ogbeide \& Aghahowa, 2005: p. 222).

The Nigerian political elites were responsible for the derailment of democratic experiments in the past. When there is strive, struggle and misunderstanding in the country (among them) over issues (ideological, political, resource etc), these elites appeal to regional, ethnic and religious sentiments (Iyekekpolo, 2020: p. 450, Ledum, 2003; Ezeani, 2003). Through these primordial sentiments, they are able to manipulate the working class and entire masses (Ogbeide \& Aghahowa, 2005: p. 223). This attitude has led to the rating of Nigeria as the $7^{\text {th }}$ poorest country in the world as well as the second most corrupt nation in the world (Transparency International, 2000). This is the premise that explains why schools, hospitals roads, electricity, water projects, and all other infrastructural facilities in Nigeria are collapsing. This, as well, explains widespread insecurity of lives and properties in Nigeria (the May 2021 killings in Owerri, Imo State and Oyo are recent instances). Violence now is a political resource. They sponsored insurgencies directly and indirectly (Iyekekpolo, 2020) such as Boko Haram and Herdsmen insurgences currently affecting Nigeria's security. Statistics have shown that corruption, political instability, poor economic growth, corruption and political instability have continued to remain pervasive in Nigeria. This is apparent from the various corruption cases and political tumult in the country (Kyarem et al., 2020). Some of the notable corruption cases include; the unaccountable $\$ 16$ billion appropriated for power project under Obasanjo administration, Diezani's corruption case involving billions of naira which led the Federal High Court to order the forfeiture of her assets worth $\$ 7.6$ billion in 2017 and the case of recovered \$9.2 million and E74 thousand cash from former group managing director of the Nigerian National Petroleum Corporation (NNPC). Others include;

${ }^{3}$ Fragile state is a state where sort authorities are not established throughout the state. State fragility is a source of transnational threats, bad governance, insecurity, of which Nigeria experiences mow. 
the charges of armed money scandal amounting to $\$ 28.3$ billion by former security adviser to President Jonathan, Col. Sambo Dasuki and the corruption charges against former secretary to the government of the federation (SGF) 5 . Additionally, desperation of power by politicians, election violence, rigging and many more are manifestations of political instability in the country (Council of Foreign Relations (CFR) Report, 2019).

Nigerian political elites spearheaded the transformations that affect the actors, context and processes to which neopatrimonialism has been associated in Nigeria. This range from tectonic drifts resulting from democratic transaction or armed uprising, and "godfather" figures associated with Nigerian political transition (Gazibo, 2012: p. 4). Political elites are godfathers who are able to dominate the public institutions by manoeuvring their protégés into elected offices and other important positions (Isaac, 2005; Ezeani, 2003). God fathers are not just financial sponsors of these office holders, but succeed in mobilization of violence, and corruption (Nwaeze, 2012) effectively enough to hobble every of their protégé over would be competitors while guaranteeing impunity for the numerous illegalities this entail (Lackey, 2012: p. 132). Again the overcentralized federalism is heads by the presidency whose enormous powers are the envy of the political power brokers, the political hawks hover if any (Moro, 2006: p. ix).

Furthermore, in a way to maintain structural power of capitalists (capitalists, in their collective role as investors, have a veto over state policies in that their failure to invest at adequate levels can create major political problems for the state managers' (Block, 1977), privatization was introduced to the Nigerian economy. The reality of capitalism favours and empowers the elite over and above the critical mass of the people in the choice of political leadership (Odubajo \& Alabi, 2014: p. 122). This has lead Nigeria (a welfarist state to become a failed capitalist state). Functional democracy is in a fragile state and being suffocated by corruption, political violence and silence in the face of quite unacceptable practices on the part of government (Ledum, 2003). The political elites, in order to become structural power capitalists, sold all belonging to Nigeria as a nation, built by older government in the name of privatization. After privatization, the problem with Nigeria increase (Onyishi, 2018; Ledum, 2003; Albieyi, 2009; Inge, 2012). The elites that bought Nigerians properties were neither real investors, nor economists and industrialists. They acquire Nigeria's properties without having the pedigree of being in industry, of production management and having no idea of economic. This is a practical disinvestment in Nigerian economy: "capital strikes as a corporate political strategy"; they destabilize national structures without repositioning the structural power they desired: Turing the economy dead.

The result of this is that there is an obvious link between "informalization" of power and the rise of personal wealth accusation networks (among the elites) prompted the emergence of a shadow Nigerian state. This relationship can be understood when we underline the contrast between the Nigerian state as it was 
meant to operate and how it actually operated (Bach \& Gazibo, 2012: p. 33; Kia \& Vurasa, 2013). The Nigerian state is today a demonized social intolerant vilified for its weakness, its over-extent, its interference with the smooth functioning of the market, its repressive character, its dependence on foreign power, its ubiquity in absence (Mkandawite, 2001: p. 289; Azaiki, 2015), all because of practices and activities of elites-political elitism.

Political elitism is now equated with the failings of the Nigerian state. It has engineered under-development (Kia \& Vurasa, 2013), emergence of petti-capitalism, structural and strategically-determined conflicts, insecurity, corruption and slippery political legacy. Nigerian political elites have turned Nigeria into informalization of powers, deinstitutionalised the nation and criminalised Nigerian politics. Nigeria, according to recent research (Rotberg \& Campbell, 2021; Kinnan, 2021) has been moved from a weak state into a fully failed state because it has manifested the signs of failed state including the inability of government to protect the citizens, large scale violence and festering insurgence.

\section{Poser for Contemporary Nigerian Elites}

The contention here is; who really rules Nigeria? There is need for political life to take new direction, which is different from the present exhibition of political shenanigans, manifesting in violence, wars, different forms of assault and hooliganism, kidnapping, killing meaningful political policies and structures. Political elites have contributed to the breakdown of political structure and governance in Nigeria (Onyishi, 2018: p. 147). There is need to create a civilization devoid of political antagonism and contemporary packaged brutalities; poor leadership leads to poor laws. Let us build our nation-state, Nigeria. We may have many reasons for the choices we make, Nigeria is the only country; state, or society, we have. Besides, the failure of Nigeria matters because the peace and prosperity of Africa has a lot to do with stability of Nigerian nation. More so, the need to prevent the spread of disorder and militancy around the globe depend on a stronger Nigeria. The spills over from Nigeria's failures ultimately affect the security of Europe and the United states (Kinnan, 2021). The state is as strong as its rulers. If Nigeria elites do not build, negotiate and develop the nation-state on strong and irrefutable philosophy, the elites remain as bad as the poor ideologies that immanent from them. They are as weak as the corruption they perform to destroy the nation-state. The civilization of a nation is proportionate to the superiority of its philosophy, and Nigeria can have no greater good than the possession of true philosophy which is a genuine civilization. This is not yet reflected in what we presently have in Nigerian public life.

\section{Recommendations}

Redefine Politics and Governance in Nigeria: The importance of governance lies in its cross-cutting roles in all the various sectors of the Nigerian economy, regional, national and local units of political and social organisation and analysis. 
The political elites' should be caution for desperation of power and common/ public interest of the society should supersede individual interest (Kyarem et al., 2020). The modus operandi of governance in Nigeria also affects its relationship with the outside world. This is so because patterns of history cast long shadows in governance which are too often poorly understood or ignore by outside development agencies (Pur \& Moore, 2007). There is need to redefine elites' interest in national issues such that politics and governance will take a neutral and at least utilitarian perspective especially at the international relations. The international dimensions of conflict, bad governance and fragile and unresponsive states are highlighted as an area of particular importance for redefinition in $\mathrm{Ni}$ gerian politics and governance. Next concerns the extent Nigerian elites interfere with foreign politics, aids and proposals, which undermine the efforts of sincere leaders to ensure good governance. There is need for checks and balances on foreign interference in the nation-state politics and governance. This could be regulated through laws and constitution and institution.

On another hand, the influence and interference of elites in politics and governance using pressure groups and other forms of informal institutions to support or undermine state-building needs regulation. In as much as informal processes emerge as vital in the political settlements, service provision and citizen engagement Nigerian-state; their activities need to be regulated. This will ensure smooth running of governance and give room for participatory politics without harm on the existing government. More importantly is the need to engage appropriate local contents in determining what development is for each region in Nigeria and what serves as a measure for determining the dividends of democracy (determining development outcomes). This will ensure that there is no bridge in the relations between government and the governed. This allows indigenous political processes for working out a country's own development and institutions to flourish. It also serves as a way for government to show direct concerns and interventions to its regions.

Dealing with Political Elites: Political elitism is now trending in Nigerian politics, power, money and access to several manipulations in the society form a trend for power in Nigeria to the detriment of the citizens. There is need for a shift in sovereignty. This shift will enable us deal with official corruption among elites (Ezeani, 2003), and strategic policy formulation that will tame the influence of these elites. This will help to reconfigure Nigerian state in such a way that its transactions will be transparent to both the citizens and the political elites.

Beyond Exclusionary Politics and the Need for Citizens Participation: Governments can become more inclusive, and therefore more stable through inclusive politics and citizen's active participation. States that are accountable only to some groups or that do not regard some members of society as "citizens" create inequalities that can fuel conflict. Osibanjo (2021) notes that it is the political elite that will determine what will take place and every conflict is a result of elite failure, the elite failure to speak up and tell the truth to their communities, which 
is the cause of every one of these civil conflicts. In this regard participation should be inclusive irrespective of gender. There are gender issues in Nigeria politics: These included the gender dimensions of conflict and inequality (Meissner, 2019; Mlambo \& Kapingura, 2019); the role of women as recipients, providers of social assistance and promoters of social activism; and the relations between gender, participation in politics and citizenship (Olugbemi \& Osuji, 2021; Edema \& Igwilo, 2020: pp. 80-83). When citizens actively participate in society through local associations and movements within the state, there are benefits to both state and society. The poor, more than any other group, rely on basic public services. For vulnerable families, access to education and healthcare are important routes out of poverty. The politics matters: services work better for the poor when poor citizens participate in reform of service delivery, hence the need to look at how this can be most effectively achieved. In conflict affected states in Nigeria, the provision of services is very sensitive. Service delivery targeting excluded groups can reduce political tensions and improve security as well.

\section{Conclusion}

The implication of this ambidextrous literature for elites is clear. In reformed transitions, there would be a considerable continuity in their composition; in revolutionary ones, the previous elites would be deposed, killed, imprisoned or driven into exile and new elite would emerge from the struggle itself. Needless to say, in practice, the contrast between the two is not so dramatic but still significant. In the former, elites circulate while in the latter, they jump. We have highlighted the role of contestation and controversy elites create in Nigerian-state. We also discussed how they influenced decisions, political processes and governance in building the public institutions that deliver development. There is need for elites to redefine their stand in Nigerian politics, develop true philosophy that will enhance indigenous political processes for working out Nigeria's own development. Thus the necessity to re-orientate Nigerian elites becomes an essential task as this research proposes because their roles in the country are failing the standard of living in Nigeria. More so they have transformed the state into a failed one. There is need to resuscitate this nation-state especially by checkmating the activities of these elites because sovereignty belongs to the people.

\section{Conflicts of Interest}

The authors declare no conflicts of interest regarding the publication of this paper.

\section{References}

Agbaje, E. B. A. (2014). Ruling Elites and the Challenges of Development in Nigerian Fourth Republic (Some Insights and Reflections from South Korea). Journal of Sustainable Development in Africa, 16, 99-121.

Albieyi, S. (2009). Public Policy in Nigeria. Ethiope Publishing Corporation.

Azaiki, S. (2015). Thoughts on Nigeria. Y Books. 
Babarinsa, D. (2003). House of War. Spectrum Books Limited.

Bach, D., \& Gazibo, M. (Eds.) (2012). Neopatrimonialism in Africa and Beyond. Routledge. https://doi.org/10.4324/9780203145623

Biggs M. (2019). Political Elites. Political Sociology. http://users.ox.ac.uk/ sfos0060/PoliticalSociology.shtml

Block, F. L. (1977). The Ruling Class Does Not Rule: Notes on the Marxist Theory of the State. Routledge.

Council of Foreign Relations (2019). Tracking Election Violence in Nigeria. https://www.cfr.org/blog/

DFID (2021). The Politics of Poverty: Elites, Citizens and State: Findings from the DFI Research on Governance and Fragile States 2001-2010. https://www.oecd.org/derec/unitedkingdom/48688822.pdf

Di John, J., \& Putzel, J. (2009). Political Settlements. Issues Paper, Governance Development Resource Centre. https://gsdrc.org/wp-content/uploads/2015/06/EIRS7.pdf

Domhoff, W. G. (1978). Who Really Rules? New Haven and Community Power Reexamined. Transaction Books.

Edema, P., \& Igwilo, M. (2020). Sex and Politics: A Hermeneutical Analysis of Women's Participation in Politics in Nigeria. Ekpoma Review, 7, 80-94.

Eke, O., Feturi, I., \& Enarum, E. (Eds.) (2005). Federal State and Resource Control in Nigeria. F. Parker Publishing Company.

Ezeajughu, M. C. (2021). Presidential Election in Nigeria: Selection or Election. Sapientia Global Journal of Arts, Humanities and Developmental Studies (SGOJAHDS), 4, 192198.

Ezeani, O. E. (2003). Public Accountability in Nigeria: Perspectives and Issues. Academic Publishing Company.

Gazibo, M. (2012). Introduction. In D. Bach, \& M. Gazibo (Eds.), Neopatrimonialism in Africa and Beyond (pp. 1-6). Routledge.

Graf, W. D. (1983). Nigerian Elite Consolidation and African Elite Theories: Toward an Explanation of African Liberal Democracy. Verfassung und Recht in Übersee/Law and Politics in Africa, Asia and Latin America, 16, 119-138. https://doi.org/10.5771/0506-7286-1983-2-119

Inge, A. (2012). Who Rules Nigeria? https://www.cmi.no/publications/4623-who-rules-nigeria

Isaac, O. A. (2005). Explaining "Godfatherism" in Nigerian Politics. African Sociological Review, 9, 79-105. https://doi.org/10.4314/asr.v9i2.23262

Itanrin, S. L. D., Olatunji, C. P., \& Osuji, U. C. (Eds.) (2018). Readings in Medieval Philosophy. Boham Publishers.

Iyekekpolo, W. O. (2020). Political Elites and the Rise of the Boko Haram Insurgency in Nigeria. Terrorism and Political Violence, 32, 749-767. https://doi.org/10.1080/09546553.2017.1400431

Kia, B., \& Vurasi Serebe, S. (2013). Political Elites and the Challenges of National Development: The Nigeria Experience. European Scientific Journal, 9, 161-172.

Kinnan, C. J. (2021). Failed State 2030: Nigeria-A Case Study. https://www.nationalpivot.com/2021/05/just-in-nigeria-is-at-point-of-n0.htmi

Kyarem, R., Sani, I. A., Oyolola, F., \& Lawal, O. (2020). Political Elites' Corruption, Political Stability and Economic Growth in Nigeria: Bound Testing Approach. Acta Universitatis Danubius, 16, 280-294. 
https://j.univ-danubius.ro/index.php/AUDOE/article/view/260/725

Lackey, C. A. (2012). The Origin and Meaning of Nigeria’s “Godfatherism” Phenomenon. In D. Bach, \& M. Gazibo (Eds.), Neopatrimonialism in Africa and Beyond (pp. 132-141). Routledge.

Langer, A (2005). Horizontal Inequalities and Violent Group Mobilisation in Côte d'Ivoire. Oxford Development Studies, 33, 25-45. https://doi.org/10.1080/13600810500099634

Langer, A. (2009). Living with Diversity: The Peaceful Management of Horizontal Inequalities in Ghana. Journal of International Development, 21, 534-546.

https://doi.org/10.1002/jid.1568

Ledum, M. (2003). Nigeria: Political Elites, Sham Democracies and the International Community.

https://www.pambazuka.org/governance/nigeria-political-elites-sham-democracies-an d-international-community

Leff, G. (1965). Medieval Thought. Pengium.

Lindemann, S. (2008). Do Inclusive Elite Bargains Matter? A Research Framework for Understanding the Causes of Civil War in Sub-Saharan Africa. Crisis States Research Centre, Discussion Paper No. 15.

Matthew, B. (2007). Elite Social Relations and Corporate Political Donations in Britain. Political Studies, 55, 59-85. https://doi.org/10.1111/j.1467-9248.2007.00622.x

Matthew, B. (2012). The Bases of Elite Social Behaviour: Patterns of Club Affiliation among Members of the House of Lords. Sociology, 46, 613-632.

https://doi.org/10.1177/0038038511428751

Meissner, R. (Ed.) (2019). Cogent Social Science, 5.

http://www.bridge.ids.ac.uk//bridge/reports gend CEP.html\#Citizenship

Mills, C. W. (1958). The Structure of Power in American Society. The British Journal of Sociology, 9, 29-41. https://doi.org/10.2307/587620

Mkandawite, T. (2001). Thinking about Developmental States in Africa. Cambridge Journal of Economics, 25, 289-314. https://doi.org/10.1093/cje/25.3.289

Mlambo, C., \& Kapingura, F. (2019). Factors influencing Women Political Participation: The Case of the SADC Region. Cogent Social Sciences, 5, Article ID: 1681048. https://doi.org/10.1080/23311886.2019.1681048

Moro, I. A. (2006). The South-South Presidency: A Right. Ebi-Ayi Publications.

Murshed, S. M., \& Gates, S. (2005). Spatial Horizontal Inequality and the Maoist Insurgency in Nepal. Review of Development Economics, 9, 121-134. https://doi.org/10.1111/j.1467-9361.2005.00267.x

Mustapha, A. B. (2009). Institutionalising Ethnic Representation: How Effective Is Affirmative Action in Nigeria? Journal of International Development, 21, 561-576.

https://doi.org/10.1002/jid.1573

Neera, C. (2010). Some Reflections on the Notion of an Inclusive Political Pact: A Perspective from Ahmedabad. Crisis States Working Paper No. 71 (Series 2).

North, D. et al. (2007). Limited Access Order in the Developing World: A New Approach to Problems of Development. World Bank Working Paper No. 4359.

https://doi.org/10.1596/1813-9450-4359

Nwaeze, C. (2012). Corruption in Nigeria Expose. Control and Surveillance Associates.

Odubajo, T., \& Alabi, B. (2014). The Elite Factor in Nigeria's Political-Power Dynamics. Journal of Studies in Social Sciences, 8, 121-139.

Ogbeide, U.-E., \& Aghahowa, J. O. (2005). Fiscal Federalism, Resource Control and the 
Nigeria Power Elite. In O. Eke, I. Feturi, \& E. Enarum (Eds.), Federal State and Resource Control in Nigeria. F. Parker Publishing Company.

Olaopa, T. (2021). Elite Nationalism and the Salvation of Nigeria. The Nation Newspapers. https://thenationonlineng.net/elite-nationalism-and-the-salvation-of-nigeria/

Olowu, D., \& Chanie, P. (Eds.) (2016). State Fragility and State Building in Africa. Springer International. https://doi.org/10.1007/978-3-319-20642-4

Olugbemi, V. K., \& Osuji, U. C. (2021). Gender Equality and National Development: A Historical Viewpoint. Sapientia Global Journal of Arts, Humanities and Developmental Studies (SGOJAHDS), 4, 390-402.

Onyishi, A. (2018). Political Elites in Nigeria and the politics of Democratization in Lieu of Democratization of Politics: Implication for Social Integration and Sustainable Development. Journal of Security Studies and Global Politics, 3, 147-155. https://doi.org/10.33865/JSSGP.003.02.0157

Orelope-Adefulire, A. V. (2022). Towards Achieving the Sustainable Development Goals in Nigeria: Bringing Women into Equation. WSDC-Adekunle Ajasin University Akungba-Akoko.

Osibanjo, Y. (2021). Osinbajo to Political Elites: Let Us Tell Our Communities the Truth. Latest News.

https://statehouse.gov.ng/news/osinbajo-to-political-elites-let-us-tell-our-communities -the-truth/

Osuji, U. C. (2018). Evolving Authenticity: A Logical Inquest from Trado-Cultural To Social-Political Ideals. Scientia: PLASU Journal of General Studies, Plateau State University, 1, 148-157.

Popkin, R. H., \& Stroll, A. (2009). Philosophy(3rd ed.). Elsevier.

Pur, K. A., \& Moore, M. (2007). Ambiguous Institutions: traditional Governance and Local Democracy in Rural India. IDS Working Paper No. 282.

Rotberg, R. I., \& Campbell, J. (2021). Nigeria is a Failed State. https://www.nationalpivot.com/2021/05/just-in-nigeria-is-at-point-of-n0.html

Schmitter, P. C. (2021). Democratization and Political Elites. Department of Political and Social Sciences European University Institute.

https://www.eui.eu/Documents/DepartmentsCentres/SPS/Profiles/Schmitter/DEMOC RATIZATION-AND-POLITICAL-ELITES.REV.pdf

Stumpf, S. (1983). Philosophy: History and Problem. McGraw Hill.

Transparency International (2000). 2000 Corruption Index, South Africa Political and Economic Monthly, 4, 27-28.

Unah, J. I. (2002). Essays in Applied Phenomenology. Foresight. 